\title{
XYLANASE PRODUCTION IN SUBMERGED FERMENTATION BY T. LONGIBRACTIUM MTCC-936
}

\author{
Ranjeet Singh \& S.K. Mandal*
}

\begin{abstract}
SUMMARY
Two thermophilic strains of fungi T.longibractium MTCC 936 and T. harzimum MTCC 792 were examined for their ability to produce Xylonase in submerged fermentations. The higher enzyme activity 27.02. was obtained in submerged fermentation by T.longibractium. The optimum yield of xylanase was obtained with xylan as a substrate along with combination of three nifrogen sources (Urea, $\left(\mathrm{NH}_{4}\right)_{2} \mathrm{SO}_{4}$, and Bactopeptone $0.1 \%$ each) of $\mathrm{pH} 6$ and temperature $55^{\circ} \mathrm{C}$. This enzyme was purified by salt precipitation and ultra filtration technique.
\end{abstract}

\section{Introduction}

Huge quantity of renewable agro product jute fibers is produced in India and Bangladesh but low quality of jute fibers often hindered our easy access to the world market. It is estimated that about $1 / 3$ of jute fibers produced are of poor quality due to higher content of hemicellulose xylan which act as a hardening agent. On the other hand cellulase free xylanase can solve these problems by their

* Department of Biochemical Engineering and Food Technology, Harcourt Butler Technological Institue, Kanpur-208002, India. Email:- Ranjeet_hbti@rediffmail.com. 
unique catalytic action. Cellulase free xylanase can selectively remove xylan from jute fibers making it more softened and attractive to the consumers. It is reported that two strain of Thermomyces lanuginosus can use for cellulase free xylanase production (Mujibur, 1998).

Microbial xylanases have potential application in the biodegradation and lignocellulosic biomass to fuels and chemicals. The cellulase free xylanases are of great interest to the pulp and paper industry because of their bleach boosting properties, which help to replace the use of damaging chemical agents. Xylanases have been purified and characterized from different sources (Neeta et al., 1995).

Xylanolytic enzyme systems are essential tools for the degradation of plant biomass, for various industries such as the pulp, paper, feed and bakery industries, (enzyme preparations are marketed containing others), potent xylan degrading systems have been identified as the important components leading to certain technological effects such as the improved bleachability of pulp, decreased viscosity of feed components or changes in dough characteristics (Dusterhoft et al., 1997).

Residual lignin is covalently bound to carbohydrate (hemicellulose) moieties and on craft pulping, this lignocarbohydrate is dissolved and redeposited on the fiber surface. It acts as a physical barrier to the entry of bleaching chemicals into the fibers and partial removal by the application of xylanases which themselves also remove chromophores, is the basis of enzyme bleach boosting effect. Minimal attack on the cellulose fiber is a prerequisite and the alternatives are to produce and apply purified enzymes or to use crude preparations from microorganisms that do not produce cellulases (Garg et.al., 1996).

Xylanase from fungi and bacteria has been studied extensively for the conversion of waste biopolymers in to xylose, can be used as a fermentation substrate for the production of single cell protein, xylitol, ethanol, organic acids and other solvents (Singh et al.,1995).

In recent years, interest has increased in the microbial xylanase for clarification of juices and for the economical production of xylose, a sweating and antidibetic agent. It is also used as digestive aid in pharmaceutical industry.

Xylanases are produced by numerous species of bacteria and fungi but the major sources are bacterial strains of genus Bacillus and fungal strains of genus Aspergillus, a range of Aspergilli including, Aspergillus fumigatus IMI 246657 (ATCC. 46324). (Stewart et al., 1985) Aspergillus ochraceous (Biswas et al., 1987); Aspergillus sydowii (Ghosh et al., 1991); Aspergillus niger (Frederick et al., 1985); Thielavia terestri ATCC 26917 (Margaritis, 1988); Humicola isolens (Dusterhoff et al., 1997); 
Humicola lanuginose (Kitpreechavanich et al., 1984); Scleratium rolfsii (Sadana et al., 1980); Trichoderma harzimum; Trichoderma longibractium (Chin Chuh et al., 1997); Trichoderma reesei (Tangu et al., 1981).

Xylanase is also produced by some bacterial strains such as Bacillus subtilis (Bernier et al.,1983); Bacillus licheniformis (Archana et al., 1997); Bacillus polymyxa (Pila ef al., 1995); Bacillus sp. BP-7 (Lopezcristina et al ., 1998); Bacillus flavotbermus and Bacillus thermolevorans (Sunna et al., 1997); Cellulomonas fini (Langsford et al., 1984); Cellulomonas flavigena ATCC 482 (Whilom et al., 1989); Clostridium stercorarium (Baerenger et al., 1985).

\section{Materials and Methods}

\section{Fungal strains}

Trichoderma harzimum MTCC 792 and Trichoderma longibractium MTCC 936 were selected for this study. Theses strains were obtained from IMT Chandigarh, India.

\section{Chemicals}

In this study sodium nitrate, dipotassium hydrogen phosphate, magnesium sulphate, potassium chloride, Sodium hydroxide, manganese sulphate, ferrous sulphate, cobalts chloride, zinc sulphate, ammonium molybedate, hydrochloric acid, diammonium sulphate, copper sulphate, disodium carbonate, cuprous oxide, phenolphtahalein, phenol, ammonium oxalate, ammonia solution, petroleum ether, rectified spirit agar agar of bacteriological grade, glucose, fructose, maltose, yeast, malt extract, xylose bactopeptone, and dextrose were used. These were procured from S.D. fine, SRL, CDH, Ranbaxy and xylan was purchased from fluka (Belgium).

\section{Equipment}

Spectronic -20 (Milton ray company U.S.A.), Spectrophotometer was used for estimation of xylose. Remi research centrifuge was used for separation of biomass. Toshniwal $\mathrm{pH}$ meter was used for $\mathrm{pH}$ adjustment of growth and fermentation media, incubator shaker (Kushner, Swizerland) was used for carrying out the submerged fermentation. 


\section{Methods}

\section{Maintenance of stock culture}

The stock culture of Trichoderma harzimum MTCC 792 and Trichoderma longibractium MTCC 936 were maintained on malt agar slants containing $(\mathrm{g} / \mathrm{l})$ malt extract, 20; agar agar 20. The initial pH of medium was adjusted to 6.5 before sterilization. These slants were inoculated with Tharzimum MTCC 792 and T. longibractium MTCC 936 incubated at $55^{\circ} \mathrm{C}$ for two days. Sub culturing was done at 30 days interval.

\section{Production media}

Different production media were used for the production of xylanase. The $\mathrm{pH}$ of each medium initially adjusted to 6 with $1 \mathrm{~N} \mathrm{HCl}$ and $1 \mathrm{NaOH}$ followed by sterilization at $121^{\circ} \mathrm{C}$ for 20 minutes.

\section{$M_{1}$ (Medium)}

The medium is used for growth and enzyme production is as follows. It is composed of $(\mathrm{g} / \mathrm{l})$ (xylan, 5.0; Urea, 0.3; Bactopeptone, 1.0; $\left(\mathrm{NH}_{4}\right)_{2} \mathrm{SO}_{4}, 1.4$; Tween80, $20 \mathrm{ml} / 1 ; \mathrm{KH}_{2} \mathrm{SO}_{4}, 2.0 ; \mathrm{CaCl}_{2}, 0.3 ; \mathrm{MgSO}_{4} .7 \mathrm{H}_{2} \mathrm{O}, 0.3 ; \mathrm{FeSO}_{4} .7 \mathrm{H}_{2} \mathrm{O}, 0.005 ;$ $\mathrm{MnSO}_{4} .7 \mathrm{H}_{2} \mathrm{O}, 0.0016 ; \mathrm{ZnSO}_{4} .7 \mathrm{H}_{2} \mathrm{O}, 0.0014,0.0014 ; \mathrm{CoCl}_{2}, 0.002$.

\section{$M_{2}$ (Medium)}

The medium containing (g/l) Maltose, $4.0 ;$ Yeast extract, $1.5 ; \mathrm{K}_{2} \mathrm{HPO}_{4} 3.5$; Trace metal solution, $1 ; \mathrm{MnSO}_{4} \cdot 4 \mathrm{H}_{2} \mathrm{O}, 0.4 ; \mathrm{FeSO}_{4} .7 \mathrm{H}_{2} \mathrm{O}, 0.25 ; \mathrm{CoCl}_{2} .6 \mathrm{H}_{2} \mathrm{O}, 0.2$; $\mathrm{ZnSO}_{4}, 7 \mathrm{H}_{2} \mathrm{O}, 0.22 ;\left(\mathrm{NH}_{4}\right)_{6} \mathrm{MO}_{7} \mathrm{O}_{24} 4 \mathrm{H}_{2} \mathrm{O}, 0.2$.

\section{$M_{3}$ (Medium)}

The medium containing (g/l) Wheat bran, $10 ; \mathrm{MgSO}_{4} .7 \mathrm{H}_{2} \mathrm{O}, 0.2 ; \mathrm{K}_{2} \mathrm{HPO}_{4}, 0.4$; $\mathrm{ZnSO}_{4} .7 \mathrm{H}_{2} \mathrm{O}, 0.2 ; \mathrm{CoCl}_{2} .6 \mathrm{H}_{2} \mathrm{O}, 0.3 ; \mathrm{NaNO}_{3}, 1.5 ; \mathrm{FeSO}_{4} .7 \mathrm{H}_{2} \mathrm{O}, 0.05$.

\section{$M_{4}$ (Medium)}

The medium containing $(\mathrm{g} / \mathrm{l})$ Wheat bran xylan, 1.0 ; Urea, $0.5 ; \mathrm{K}_{2} \mathrm{HPO}_{4}, 1.0$; $\mathrm{MgSO}_{4} .7 \mathrm{H}_{2} \mathrm{O}, 0.5 ; \mathrm{KCl}, 0.2$. 


\section{$M_{s}$ (Medium)}

The medium containing ( $\mathrm{g} / \mathrm{l})$ Gelatin,0.5; Peptone, $0.3 ; \mathrm{KH}_{2} \mathrm{PO}_{4}, 0.2$; $\mathrm{MgSO}_{4} .7 \mathrm{H}_{2} \mathrm{O}, 0.2 ;$ Yeast extract, 0.3 .

\section{Assay of xylanase activity}

Xylanase activity was assayed on the xylose liberated by the hydrolysis of $x y l a n$. The xylanase present in supernatant of fermented broth used for estimation of xylose produced after hydrolysis of xylan by this enzyme.

One unit of xylanase activity is defined as the amount of enzyme that produced l $\mu$ mol of xylose per ml per minute from xylan under assay conditions.

The reaction mixture containing $1 \mathrm{ml}$ xylan solution of concentration $\mathrm{lg} / 100 \mathrm{ml}$ and $1 \mathrm{ml}$ supernatant obtained after centrifugation of fermented broth. The mixture was kept in water bath maintained at $55^{\circ} \mathrm{C}$ for 10 minutes to allow the reaction to proceed. After $10 \mathrm{~min}$. the reaction was stopped by addition of $1 \mathrm{mIDNS}$ reagent. (Miller, 1959). Now this solution was heated in boiling water bath. After 5 minutes the test tubes were removed from the water bath and cooled to $30^{\circ} \mathrm{C}$, the colour of solution becomes yellowish to reddish brown, and then total volume was made to $20 \mathrm{ml}$ by adding distilled water in each test tube a blank (without xylose) was also run simultaneously. Then the absorbance was measured in spectronic 20 at $540 \mathrm{~nm}$. The xylose concentration in each test tube was determined by comparing with standard curve for Xylose (1 to $5 \mathrm{~g} / \mathrm{l})$.

\section{Results and Discussion}

A comparative study between Trichoderma longibractium and Trichoderma harzimum for xylanase production indicated that T. longibractium was better source of xylanase than Trichoderma harzimum. Further work was carried out to optimize culture condition viz. medium composition, $\mathrm{pH}$, temperature, effect of carbon and nitrogen sources on enzyme production during this study.

\section{Selection of microorganism on the basis of production media.}

Xylanase production was carried out with $T$. longibractium and T. harzimum in different media by submerged fermentations in $250 \mathrm{ml}$ broth with $5 \% \mathrm{v} / \mathrm{v}$ inoculum in $500 \mathrm{ml}$ Erlenmeyer flask. The results were indicated in Table 1 and Table 2. 
Table 1. Xylanase production by T.longibractium in different media $\left(\mathrm{M}_{1}-\mathrm{M}_{5}\right)$ at $55^{\circ} \mathrm{C}$ and $\mathrm{pH} 6$.

Production of xylanase in terms of activity $\mathrm{U} / \mathrm{ml}$ in various media

\begin{tabular}{|l|l|l|l|l|l|}
\hline $\begin{array}{l}\text { Fermentation } \\
\text { duration (days) }\end{array}$ & $M_{1}$ & $M_{2}$ & $M_{3}$ & $M_{4}$ & $M_{5}$ \\
\hline 3 & 7.20 & 3.20 & 6.0 & 5.60 & 2.00 \\
4 & 12.80 & 7.20 & 9.20 & 9.00 & 6.0 \\
5 & 14.80 & 9.00 & 10.40 & 10.40 & 8.0 \\
6 & 15.70 & 10.40 & 12.60 & 12.80 & 9.5 \\
7 & 17.90 & 12.00 & 14.00 & 15.60 & 9.6 \\
8 & 16.00 & 9.6 & 12.80 & 14.80 & 9.20 \\
9 & 15.20 & 9.0 & 12.00 & 13.20 & 8.4 \\
\hline
\end{tabular}

Table 2. Xylanase production by $T$. harzimum in different media $\left(M_{1}-M_{5}\right)$ at temperature $55^{\circ} \mathrm{C}$ and at $\mathrm{pH} 6$.

Production of xylanase in terms of activity $\mathrm{U} / \mathrm{ml}$ in various media

\begin{tabular}{|l|l|l|l|l|l|}
\hline $\begin{array}{l}\text { Fermentation } \\
\text { duration (days) }\end{array}$ & $M_{1}$ & $M_{2}$ & $M_{3}$ & $M_{4}$ & $M_{5}$ \\
\hline 3 & 6.80 & 2.00 & 5.60 & 5.2 & 2.80 \\
4 & 9.6 & 7.00 & 9.0 & 8.20 & 6.00 \\
5 & 12.00 & 8.4 & 9.6 & 9.4 & 7.20 \\
6 & 14.00 & 9.6 & 11.00 & 11.10 & 8.4 \\
7 & 16.00 & 11.00 & 12.80 & 12.60 & 9.5 \\
8 & 15.60 & 10.40 & 12.60 & 11.90 & 8.4 \\
9 & 13.80 & 9.6 & 10.80 & 10.40 & 7.0 \\
\hline
\end{tabular}

The results from Table 1 and Table 2 and also Fig 1 and Fig 2 obvisouly indicate that Trichoderma longibractium gave comparatively higher enzyme activity than Trichoderma harzimum for media $M_{1}$ to $M_{5}$. The optimum enzyme activity in case of Trichoderma longibractium (Table 1 and Fig 1) was observed to be $17.90 \mathrm{U} / \mathrm{ml}$ 
whereas it was $16.00 \mathrm{U} / \mathrm{ml}$ in case of Trichoderma harzimum (Table 2 and Fig 2) in $M_{1}$ medium for 7 days fermentation.
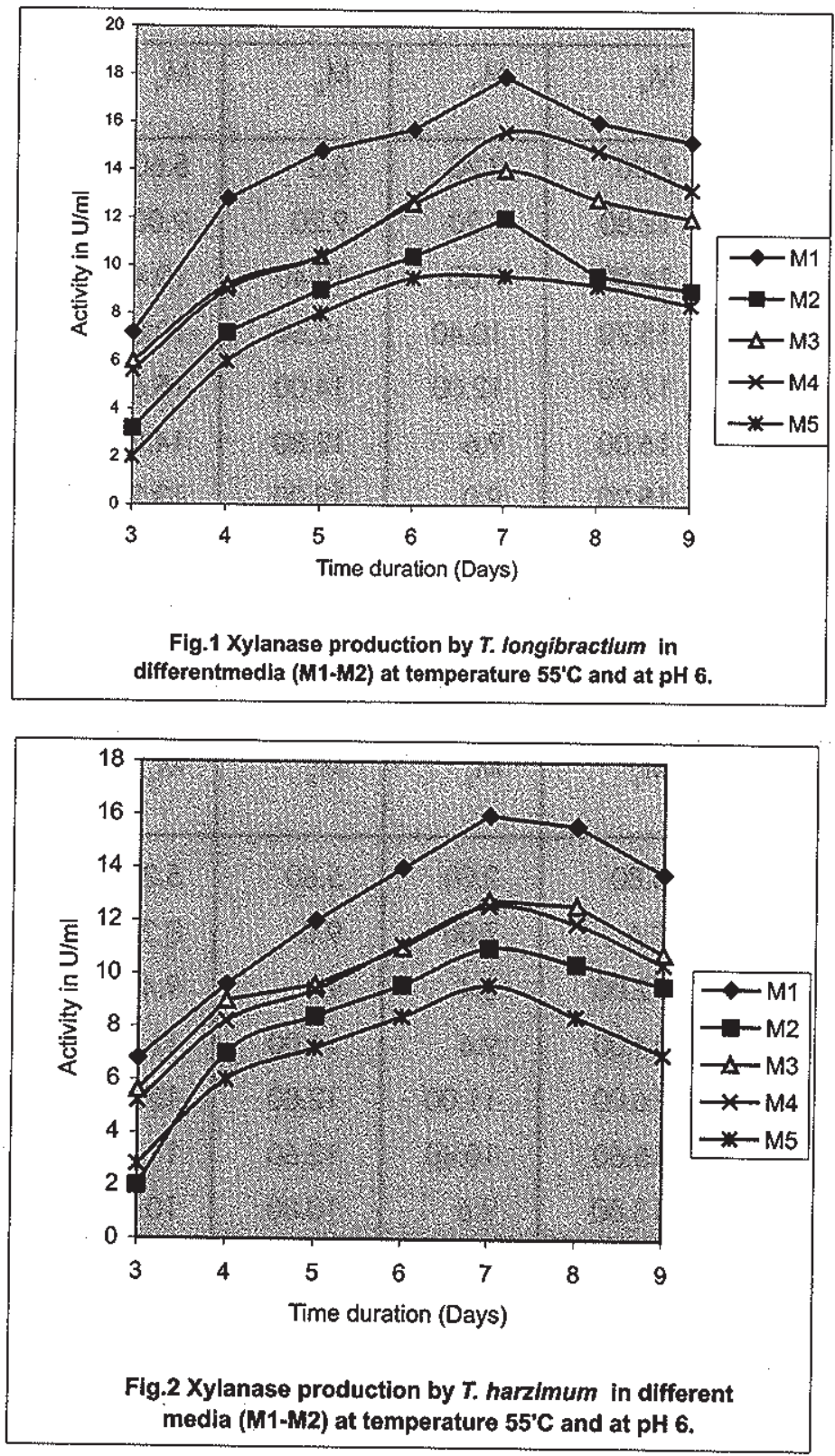


\section{Optimization of pH for xylanase production by T. longibractium}

Submerged fermentation in $250 \mathrm{ml}$ broth with $5 \% \mathrm{v} / \mathrm{v}$ in $500 \mathrm{ml}$ Erlenmeyer flask was carried out with $M_{1}$ medium for 7 days at $55^{\circ} \mathrm{C}$ by adjusting various $\mathrm{pH}$ of the medium with phosphate buffer. Experimental results are shown in Table 3.

Table 3. Effect of $\mathrm{pH}$ or the production of xylanase by submerged fermentation at $55^{\circ} \mathrm{C}$ for 7 days fermentation.

\begin{tabular}{|c|c|}
\hline $\mathrm{pH}$ of production medium & Production of xylanase in terms of activity $(\mathrm{U} / \mathrm{ml})$ \\
\hline 3 & 10.40 \\
4 & 12.80 \\
5 & 15.20 \\
6 & 17.90 \\
6.5 & 16.50 \\
7 & 15.60 \\
7.5 & 15.00 \\
\hline
\end{tabular}

The data from Table 3 indicate that the enzyme yield gradually increases with increasing $\mathrm{pH}$ value from 3 to 6 and after that it was decreased significantly and the optimum pH was 6 at which enzyme activity was $17.90 \mathrm{U} / \mathrm{ml}$.

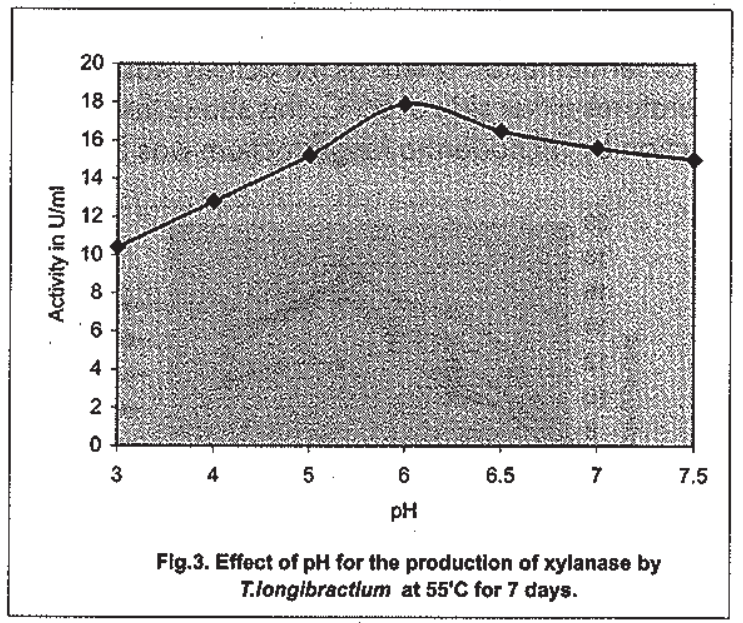




\section{Optimization of temperature for xylanase production by $T$. longibractium}

Several experiments have been carried out by submerged fermentation with $250 \mathrm{ml}$ in $500 \mathrm{ml}$ Erlenmeyer flask under static condition with T. longibractium MTCC 936 at various temperatures $35^{\circ} \mathrm{C}$ to $65^{\circ} \mathrm{C}$ for temperature optimization for the xylanase production.

Table 4. The effect of temperature on production of xylanase by Trichoderma longibractium MTCC 936 in $\mathrm{M}_{1}$ production medium at $\mathrm{pH} 6$ for 7 days fermentation.

Activity in $\mathrm{U} / \mathrm{ml}$ at various temperature

\begin{tabular}{|l|l|l|l|l|l|l|}
\hline $\begin{array}{l}\text { Fermentation } \\
\text { duration (days) }\end{array}$ & $35^{\circ} \mathrm{C}$ & $45^{\circ} \mathrm{C}$ & $50^{\circ} \mathrm{C}$ & $55^{\circ} \mathrm{C}$ & $60^{\circ} \mathrm{C}$ & $65^{\circ} \mathrm{C}$ \\
\hline 3 & 6.0 & 6.20 & 6.70 & 7.20 & 7.00 & 7.00 \\
4 & 9.20 & 9.00 & 10.20 & 12.80 & 11.40 & 10.00 \\
5 & 10.20 & 11.00 & 12.00 & 14.80 & 13.20 & 12.00 \\
6 & 12.80 & 13.20 & 13.90 & 15.80 & 14.30 & 13.60 \\
7 & 12.00 & 16.00 & 16.80 & 17.90 & 16.40 & 15.60 \\
8 & 12.00 & 14.80 & 15.20 & 16.00 & 15.00 & 14.80 \\
9 & 11.00 & 12.60 & 13.80 & 15.00 & 14.00 & 13.80 \\
\hline
\end{tabular}

The experimental results are indicated in Table 4 and Fig. 4, show the enzyme activity at different temperatures ranging from $35^{\circ} \mathrm{C}$ to $65^{\circ} \mathrm{C}$. Results clearly indicate that the best activity $(17.90 \mathrm{U} / \mathrm{ml})$ was achieved at relatively higher temperature i.e. $55^{\circ} \mathrm{C}$ after 7 days of fermentation where as the activity was varied from $6 \mathrm{U} / \mathrm{ml}$ to $16 \mathrm{U} / \mathrm{ml}$ for temperatures either side of $55^{\circ} \mathrm{C}$, this shows the optimum temperature for enzyme production by Trichoderma longibractium was $55^{\circ} \mathrm{C}$.

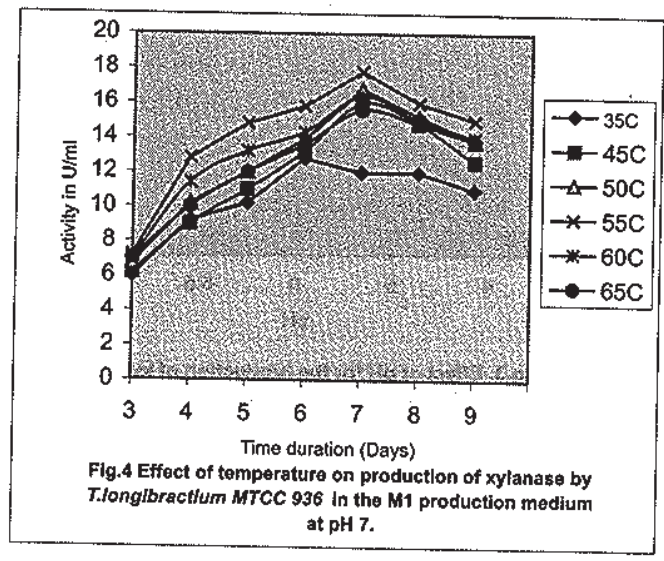


Table 5. Effect of nitrogen sources on the production of xylanase by Trichoderma longibractium MTCC 936 in medium $M_{1}$ except nitrogen sources at $\mathrm{pH} 6$ and $55^{\circ} \mathrm{C}$ for 7 days fermentation.

\begin{tabular}{|l|l|}
\hline Nitrogen source (0.3\%) & Activity in U/ml. \\
\hline$\left(\mathrm{NH}_{4}\right)_{2} \mathrm{SO}_{4}$ & 14.80 \\
Urea & 15.70 \\
Bactopeptone & 16.20 \\
$\left(\mathrm{NH}_{4}\right)_{2} \mathrm{SO}_{4}+$ Urea + Bactopeptone & \\
$0.1 \% \quad 0.1 \% \quad 0.1 \%$ & 17.90 \\
\hline
\end{tabular}

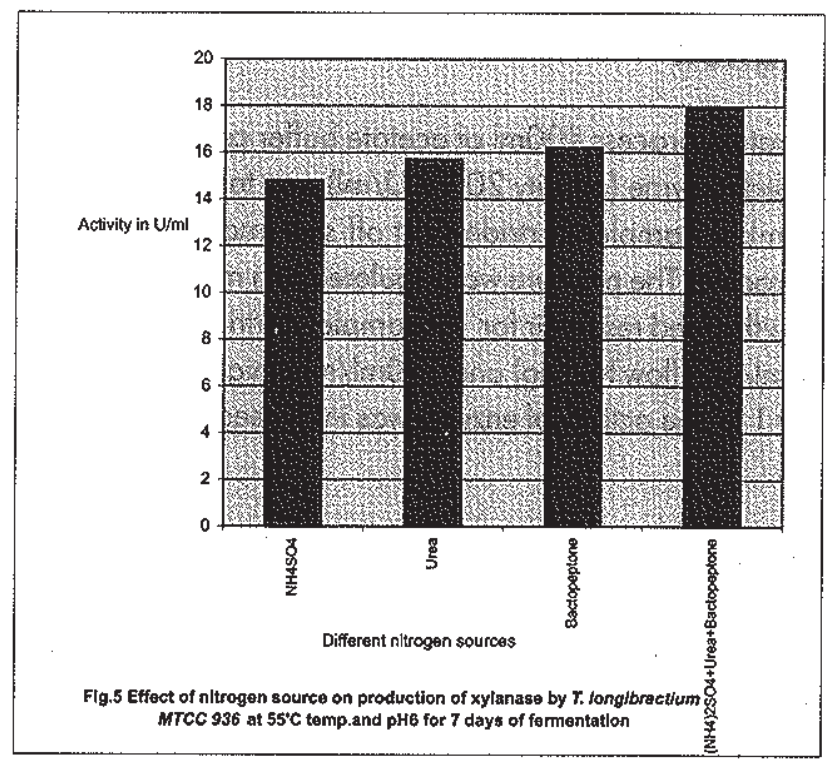

Various nitrogen sources like urea, $\left(\mathrm{NH}_{4}\right)_{2} \mathrm{SO}_{4}$, bactopeptone were used for the production of xylanase along with the medium $\mathrm{Ml}$ ( without nitrogen source). The production of xylanase are mentioned in Table 5. Which indicates that xylanase yield in term of activity was low in term of activity in case of (Nitrogen sources such as $\left(\mathrm{NH}_{4}\right)_{2} \mathrm{SO}_{4}$, urea, Bactopeptone $(14.80,15.70,16.20 \mathrm{U} / \mathrm{ml})$ respectively, whereas combination of these three nitrogen sources produces better yield of enzyme 17.90 $\mathrm{U} / \mathrm{ml}$ respectively. 


\section{Purification of Enzyme}

The purification of enzyme was done in the following steps:-

\section{Ammonium sulphate precipitation}

The fermented broth $400 \mathrm{ml}$ was centrifuged at $5000 \mathrm{rpm}$. for $10 \mathrm{~min}$. to remove biomass. This was followed by addition of $60 \%$ ammonium sulphate solution to precipitate the enzyme present in the supernatant obtained after centrifugation. The precipitate was collected on whatman filter paper No. 40 and mixed in $0.05 \mathrm{M}$ acetate buffer $(400 \mathrm{ml})$.

\section{Ultra filtration}

In the ultra filtration process $400 \mathrm{ml}$ of acetate buffer containing above suspended partially purified enzyme (activity $20.92 \mathrm{U} / \mathrm{ml}$ ) was taken in the reservoir of ultra filtration assembly. Xampler cartridge cut off size (mol wt. 10,000-15,000) was used for this process. The pressure was regulated to a maximum 10 to $15 \mathrm{psig} 10.7$ to $1 \mathrm{barg}$ ) in to the feed reservoir for $1 \mathrm{M}$ xampler cartridge nominal feed flow rates are used $100 \mathrm{ml} / \mathrm{min}$ (low fouling) and $190 \mathrm{ml} / \mathrm{min}$ (high fouling) ultra filtration was carried out for $1 \mathrm{hr}$. the activity of enzyme was increased 20.92 to $27.02 \mathrm{U} / \mathrm{ml}$ after ultra filtration.

\section{Conclusion}

Xylanase production in submerged fermentation was carried out with Trichoderma harzimum MTCC 792 and Trichoderma longibractium MTCC 936 but the highest enzyme activity $(17.90 \mathrm{U} / \mathrm{ml})$ was obtained in case of Trichoderam harzimum as shown in Table 1.

Experimental results indicate that xylanase production was most suitable with Trichoderma longibractium MTCC 936 in medium $M_{1}$ at $\mathrm{pH} 6$ and $55^{\circ} \mathrm{C}$ for 7 days fermentation.

The production of xylanase was greatly influenced by $\mathrm{pH}$ of production medium. There was a gradual increase in enzyme production with increase of $\mathrm{pH}$ value from 3 to 6 and thereafter- significant reduction was observed (Table 3). 
The effect of nitrogen sources was also studied it is interesting to note that better yield of enzyme (Table 5) was obtained when a combination of three nitrogen sources are used with medium $M_{1}$.

The production of xylanase enzyme in submerged fermentation was greatly influenced by temperature also. There was a gradual increase in activity up to $55^{\circ} \mathrm{c}$ followed by significant reduction at higher fermentation temperatures.

The study suggests that use of xylanase in purified form gave better results as compared to crude enzyme. However purification of enzyme is expensive hence there is need to search for high yielding microbial strain and to develop cost effective methods for xylanase production and purification.

\section{References}

1. Archaria, A. and Satyanaryan T., 1997. Xylonase production by thermophilic Bacillus. A99 in solid-state fermentation. Enzyme and Microbial Technology 21, 12-17.

2. Biswas, S.R., Mishra, A.K., and Nanda, G., 1986. Xylanolytic activity of Aspergillus ochroceous-42. Current science 55, 7, 351-352.

3. Chen, C.S., Chen Jam-Lin and Tse-Yang lin. 1997. Purification and characterization of a xylanase from Trichoderma for xylooligosaccharide production. Enzyme and Microbial Technology 21, 91-96.

4. Dusterhoft, E.M., Linseen, V.A.J.M., Vorgen, A.G.J. and Beldman 1997. Purification, characterization and properties of two xylanase from Humicola insolens. Enzyme and Microbial Technology 20, 437-445.

5. Garg, A.P., Roberts, J.C. and Mc carthy A. J. 1998. Bleach boosting effect of Streptomyces thermoviolaceus and its comparison with two commercial enzyme prepartions on birchwood kraft pulp. Enzyme and Microbial Technology 22, 594-598.

6. Garg, A.P., Mccarthy, A.J. and J.C. Roberts 1996. Bioleaching effect of Streptomyces thermoviolaceus xylanase preparation on birch wood kraft pulp. Enzyme and Microbial Technology 18, 261-267.

7. Ghosh, M., and Nanda, G. 1991. Immobilized Aspergillus sydowii produces xylanase. Biotechnology letters 13, 11, 807-808.

8. Kitpreechavanich, V., Mitsunori and Nagai, S. 1984. Purification and propenties of Endol$4 \beta$-xylanase from Humicola lanuginosa. Fermentation Technology $62,5,415-420$.

9. Kulkami, N., Chauthawale, J.and Rao, M.1995. Characterization of the recombinant xylanoses in Escherichio coli from an alkaliphilic thermophilic Bacillus SP NCIM 59. Enzyme and Microbial Technology 17, 972-976. 
10. Mercahnt, R., Merchant, F.and Margaritis A. 1998. Production of xylanase by the thermophilic fungus Thelovia terrestris. Biotechnology letters 10, 7, 513-516.

11. Miller, G.L. 1959 Analytical chemistry 31, 426-428.

12. Singh, A., Chander R., Kuhad and Kumar, M. 1995. Xylanase production by hypenalanolytic mutant of Fusarium oxysporum. Enzyme and Microbial Technology 17, 551-553.

13. Steward, J.C., Laster, A., Milburn, B. and Heptinstall, J. 1985. Xylanase enzymes of Aspergillus fumigatus fresenius. Biotechnology letters 7, 8, 581-584.

14. Whelan, H.A. and Pembroke, J.T. 1989. The effect of protease on stability of cellulase and xylanase from Cellulomonas flovigeno. Biotechnology letters 11, 12, 891.894. 